\title{
Música y transferencia de habilidades: revisión bibliográfica descriptiva para el siglo XXI
}

\author{
Music and skills transfer: a descriptive bibliographic review \\ for the 21st century
}

\author{
por \\ Felipe I. Porflitt Becerra \\ Facultad de Educación, Pontificia Universidad Católica de Chile, Chile \\ felipe@uc.cl
}

Las habilidades que se requieren para apreciar la música o tocar instrumentos musicales son diversas. Algunas de ellas son simples, y otras requieren de un desarrollo en el tiempo debido a su complejidad, la que generalmente se da por la perseverancia del estudio de la música en sí. Desde el punto de vista de la disciplina, el valor de la música para la humanidad no ha tenido lugar a dudas en ninguna era. Sin embargo, desde otras disciplinas, los alcances de la música fuera de esta generan diversos tipos de interrogantes. Existe evidencia metaanalítica que tiende a mostrar que los efectos de la música podrían estar sobreestimados en su transferencia de habilidades (Sala y Gobet 2017), pero se vuelve contradictoria al revisar exhaustivamente lo que ofrece la literatura en los últimos años. Considerando ese problema, este artículo describe cómo se ha distribuido la investigación dentro y fuera de la disciplina de la música durante el siglo XXI. Una búsqueda detallada de bibliografía muestra que el número de artículos que indagan en la transferencia de habilidades cercanas y lejanas, ha ido incrementándose en los últimos veinte años, siendo las habilidades lejanas las que muestran mayor crecimiento, y dejando de lado algunos tópicos que sería interesante de indagar en futuras investigaciones.

Palabras clave: Transferencia de habilidades, educación musical, entrenamiento musical, investigación en música.

The skills required to appreciate music or play musical instruments are diverse. Some of them are simple, and others require development over time given their complexity, which generally responds to the perseverance of the study of music itself. From the point of view of the discipline, the value of music for humanity has not taken any doubt in any era. However, from other disciplines, the scope of music outside itself generates various types of questions. There is meta-analytical evidence that tends to show that the effects of music may be over-estimated in their transfer of skills (Sala $\mathcal{E}$ Gobet 2017), but it becomes contradictory when we thoroughly review what literature offers in recent years. Considering that problem, this article describes how research has been distributed inside and outside the music discipline during the $21^{\text {st }}$ century. A detailed literature search shows that the number of articles that investigate for the transfer of near and far skills has been increasing in the last 20 years, with far skills being the ones that show the greatest growth and leaving aside some topics that would be interesting to investigate in future research.

Keywords: Skills transfer, music education, music performance, music research. 


\section{INTRODUCCIÓN}

La discusión en torno a la existencia de una transferencia de habilidades de un entrenamiento a otro es muy antigua (Singley y Anderson 1989; Taatgen, 2013; Thorndike y Woodworth 1901), incluso, en la actualidad la literatura ofrece una propuesta taxonómica para este tipo de transferencias de habilidades, razonable de proponer según evidencia en diversos campos (Barnett y Ceci 2002). No obstante la discusión histórica del concepto, el término de transferencia de habilidades se sigue entendiendo en dos niveles: la transferencia cercana, referida a la generalización de habilidades por medio de dominios similares (e.g, aprender a tocar un violín genera cambios favorables en la motricidad fina), y la transferencia lejana, relación que depende de las dimensiones contextuales y de los contenidos que se estén estudiando, entre dos variables que no pertenecen a dominios similares (e.g. aprender ajedrez genera cambios favorables en las habilidades matemáticas).

Pensado desde la disciplina de la música y en un ámbito más amplio, el impacto de la educación musical ha mostrado dos grandes categorías en sus líneas de investigación, propuestas como "dentro" y "fuera" de la música según Carrillo, Viladot y Pérez-Moreno (2017). En este paradigma se aprecian muchos ejemplos para el primer caso (dentro de la música); así, desde la educación musical existe tanto evidencia empírica como teórica en diversos niveles educativos y culturas, del estudio de la música y sus subáreas, por ejemplo: apreciación musical (Menezes y Abud 2016; Nethsinghe 2012; Silveira 2014), composición (Beineke y Zanetta 2014; Deemer 2016), improvisación (Heunis 2013), estética (Seidl 2011; Wade 1975), interpretación (Blom 2006; Floyd 1981), dirección coral y orquestal (Bodnar 2017; Latimer 2018), producción musical (Hughes 2018; Toulson y Hepworth-Sawyer 2018), o radiodifusión (Cooper 2005). Desde este y muchos otros paradigmas, el valor de la música en sí misma nunca ha tenido lugar a dudas.

Sin embargo, existe otro extremo de las investigaciones, que ha abierto interrogantes más difíciles de responder, respecto específicamente del valor de la música fuera de sí misma. Ciertamente, no es fácil contestar a la inquietud acerca del impacto, el aporte, o el efecto de la música en el desarrollo de la humanidad. Lo único que se torna evidente, es que desde que existe registro alguno de cultura, hay evidencia de que la música ha acompañado al ser humano (e.g. el caso de los sumerios, Cheng 2009). Tratar a la música fuera del valor que tiene en sí misma, pareciera ser un ejercicio poco amigable para la disciplina, pero el hecho de tratarla como una variable que modere o medie efectos hacia la transferencia de otras habilidades se torna razonable, en un contexto educacional que muestra características y tendencias actuales hacia la inclusión, diversidad e interdisciplina. De esta manera, es posible ampliar las fronteras de las investigaciones a campos como las ciencias sociales, naturales, de la salud, las humanidades, entre muchas otras.

Según Sala y Gobet (2017), y Sala et al. (2019) existen habilidades cercanas, que con evidencia robusta (datos de metaanálisis de primer y segundo orden) el ejercicio musical es capaz de potenciar (e.g. motricidad fina, discriminación auditiva). Sin embargo, los mismos autores plantean que existen dudas respecto de la transferencia de habilidades lejanas que se puedan potenciar por diversos entrenamientos (i.e. cognitivos, sociales, emocionales, académicos, etc.), como el caso del entrenamiento musical, el ajedrez o los videojuegos. Plantean que, lo más probable, es que cuando se adquiere una habilidad otorgada por estos tipos de entrenamiento, únicamente se entrena esa habilidad, sin transferencia lejana, o con una transferencia con un tamaño de efecto cercano a cero. El hecho es que sus artículos muestran algunas inconsistencias, como en el caso específico del entrenamiento musical, donde reportan un tamaño de efecto $\eta^{2}=.16$, que pese a ser pequeño (Cohen 1988; Bakker et al. 2019), no es cero. En cambio, revisiones de otros estudios de transferencia y entrenamiento musical han mostrado evidencia contraria. Miendlarzewska y Trost (2014) 
por ejemplo, realizan una revisión de investigaciones hasta 2014 donde se muestra que hay habilidades lejanas, como funciones ejecutivas o habilidades del lenguaje como escuchar y leer, que se potencian con el ejercicio musical, aunque estarían en duda algunas de otro orden, como las habilidades sociales, la memoria verbal o la inteligencia genérica.

Un aspecto importante que se aprecia en la investigación que estudia estos ámbitos es que disciplinas como psicología, neurociencias, educación, o ciencias sociales en general plantean preguntas que tienden ir más a la base de los sucesos que a los detalles. Un ejemplo de ello es que, en este estudio, la motivación principal nació de manera posterior al análisis de tres artículos de una tesis de doctorado por parte de una comisión de cinco personas, en que se aprecia, con una muestra grande ( $\mathrm{N}=144)$, que los músicos tienen un mayor desempeño cognitivo que no músicos (Porflitt y Rosas 2019); que los músicos tienen características cognitivas distintas entre instrumentistas rítmicos, melódicos y armónicos (Porflitt y Rosas 2020a); y que, a mayor sofisticación musical, se observa que los procesos cognitivos se ven favorecidos de manera más robusta (Porflitt y Rosas 2020b). Surgen tres preguntas importantes observando esta evidencia: a) ¿las habilidades dadas por el entrenamiento musical instrumental se transfieren a dominios lejanos? (que es el tópico del presente estudio), b) ¿cuál podría ser la causa probable de estos efectos? (que es una pregunta larga de responder), y c) ¿cuáles son las bases neurológicas que soportan estos hallazgos? (pregunta aún más larga de responder).

Así, no siempre la literatura responde, de manera cinética, a las discusiones que tienen lugar en campos tan específicos como la transferencia de habilidades y el entrenamiento musical. Pese a ello, con hallazgos contradictorios en torno a estos tópicos, se vuelve razonable indagar en cuáles son los factores externos (las variables que se han estudiado de manera sistemática), que han sido abarcados en la investigación referente a la música en los últimos años, y en cómo los distintos estudios están distribuidos para la transferencia de habilidades cercanas y lejanas. Estos tópicos estarían trazados en dos líneas; a) la educación musical entendida de manera íntegra, y también b) las relaciones del entrenamiento musical instrumental, que ha sido el que en mayor proporción abarcan los estudios.

Para indagar en las líneas de investigación que se exponen en este marco teórico, el objetivo del presente estudio es dar a conocer los límites con los que hemos estado trabajando en lo transcurrido del siglo XXI. Específicamente, se propone revisar los alcances extramusicales de la música y, con ello, mostrar la distribución que tienen algunas variables en la literatura para transferencia de habilidades cercanas y lejanas, otorgadas por la educación o el entrenamiento musical.

\section{MÉTODO}

Se realizó una recolección de artículos en revistas científicas, en las bases de datos Web of Science (WoS), Scopus y Scielo, utilizando el criterio de búsqueda skill music transfer, y transferencia habilidades música. La búsqueda se hizo con el filtro articles, con el objetivo de abarcar en mayor proporción estudios que tuvieran evidencia empírica. Únicamente en WoS la búsqueda tuvo resultados, y solo con la primera entrada (en inglés). Así, la búsqueda dio un resultado de 207 artículos. Se revisaron los resúmenes de la totalidad de los artículos de manera minuciosa. Posteriormente, se descartaron los estudios que no se vincularan con algún tipo de transferencia de habilidades, estudios puramente teóricos o con modelos sin evidencia empírica, estudios que fueran reportes de otros estudios (con los mismos datos), y estudios que midieran su(s) variable(s) dependiente(s) en algún ámbito puramente musical (dentro de la música). Como paso intermedio, hubo 48 investigaciones que cumplieron con el criterio de inclusión, consistente básicamente en que mostraran datos 
de transferencia de habilidades lejanas o cercanas, desde la educación musical (integral) o desde el entrenamiento musical (interpretación o apreciación musical).

Posteriormente, se generó una tabla que muestra las autorías, año de publicación, la(s) variable(s) dependiente(s) que incluye cada estudio, el número de participantes, el rango etario, tipo de desarrollo, tipo de entrenamiento musical y la metodología utilizada. El Anexo 1 muestra esta información detallada en orden cronológico.

\section{ANÁLISIS Y RESULTADOS}

Se recogieron 127 variables dependientes de los 48 estudios. Como análisis exploratorios, se generaron las tablas presentadas a continuación, cada una de ellas considerando únicamente los porcentajes de distribución de los estudios para las siguientes categorías: tipo de metodología (ver Tabla 1), rangos etarios (ver Tabla 2), tipo de desarrollo (ver Tabla 3), y el tipo de entrenamiento musical (ver Tabla 4). Es importante destacar que el tamaño muestral total (i.e. la suma de todos los participantes de cada uno de los estudios) fue de $\mathrm{N}=2549$, donde una sola investigación no declaró la muestra.

\section{TABLA 1: DISTRIBUCIÓN POR TIPO DE METODOLOGÍA (PORCENTAJES)}

\begin{tabular}{|c|c|}
\hline Tipo de metodología & Porcentaje de estudios \\
\hline Cuantitativa & 91,67 \\
\hline Cualitativa & 8,33 \\
\hline
\end{tabular}

Fuente: Elaboración propia.

TABLA 2: DISTRIBUGIÓN POR RANGOS ETARIOS (PORCENTAJES)

\begin{tabular}{|c|c|}
\hline Rango etario & Porcentaje de estudios \\
\hline Niños & 54,2 \\
\hline Adolescentes & 27 \\
\hline Adultos & 37,5 \\
\hline Adultos mayores & 10 \\
\hline
\end{tabular}

Fuente: Elaboración propia.

Nota: los porcentajes en total no suman $100 \%$, porque algunos estudios abarcaron más de una categoría de rango etario. Se consideraron las siguientes edades para construir los rangos (años): niños (3 a 10), adolescentes (11 a 17), adultos (18 a 60), y adultos mayores (61 en adelante). 


\section{TABLA 3: DISTRIBUCIÓN POR TIPO DE DESARROLLO (PORCENTAJES)}

\begin{tabular}{|c|c|}
\hline Tipo de desarrollo & Porcentaje de estudios \\
\hline Típico & 85,42 \\
\hline Implantes cocleares & 6,25 \\
\hline Déficit sintáctico & 2,1 \\
\hline Dislexia & 2,1 \\
\hline Migrantes & 2,1 \\
\hline Estrés & 2,1 \\
\hline Ansiedad & 2,1 \\
\hline Alzheimer & 2,1 \\
\hline
\end{tabular}

Fuente: Elaboración propia.

Nota: los porcentajes en total no suman $100 \%$, porque algunos estudios abarcaron más de una categoría de tipo de desarrollo.

TABLA 4: DISTRIBUCIÓN POR TIPO DE ENTRENAMIENTO MUSICAL (PORCENTAJES)

\begin{tabular}{|c|c|}
\hline Tipo de entrenamiento musical & Porcentaje de estudios \\
\hline Interpretación & 64,6 \\
\hline Apreciación & 35,41 \\
\hline Creación & 2,1 \\
\hline Teoría de la música & 2,1 \\
\hline Didáctica de la música & 2,1 \\
\hline
\end{tabular}

Fuente: Elaboración propia.

Nota: los porcentajes en total no suman $100 \%$, porque algunos estudios abarcaron más de una categoría de tipo de entrenamiento musical.

Posteriormente, se utilizó el modelo de Miendlarzewska y Trost (2014) para categorizar las variables, donde se muestran tres índices para transferencia cercana (habilidades motoras finas, habilidades de escucha, procesamiento temporal y orientación en el tiempo) y 
cinco para transferencia lejana (memoria verbal, habilidades sociales, inteligencia genérica, funciones ejecutivas, $y$ habilidades de escucha y lectura). Debido a que existieron variables dependientes que no se ajustaban al modelo propuesto por Miendlarzewska y Trost (2014), se generaron cuatro índices adicionales para categorizar las variables dependientes (desempeño académico, creatividad, etnia y evidencia neurocientífica). Estas nuevas categorías se sugieren debido a las características de los estudios analizados. De esta manera, cada variable se categorizó en alguno de estos doce índices, donde no todas las investigaciones definen de la misma manera sus variables (i.e. con el mismo nombre), aunque, contradictoriamente, en un número considerable de casos pertenecen a ámbitos similares. Los porcentajes de distribución de variables dependientes se muestran en la Tabla 5 (ver Tabla 5).

\section{TABLA 5: DISTRIBUCIÓN DE VARIABLES DEPENDIENTES (PORCENTAJES)}

\begin{tabular}{|c|c|c|c|c|c|c|c|c|c|c|c|c|c|}
\hline \multicolumn{10}{|c|}{} & \multicolumn{4}{|c|}{$\begin{array}{c}\text { Categorías propuestas } \\
\text { en este estudio }\end{array}$} \\
\hline $\mathrm{a}$ & $\mathrm{b}$ & $\mathrm{c}$ & & $\mathrm{d}$ & $\mathrm{e}$ & $\mathrm{f}$ & $\mathrm{g}$ & $\mathrm{h}$ & $\mathrm{i}$ & $\mathrm{j}$ & $\mathrm{k}$ & $\mathrm{l}$ \\
\hline 7,8 & 5,5 & 7,1 & 7,1 & 11,8 & 27,5 & 15,7 & 7,1 & 4,7 & 2,4 & 0,9 & 2,4 \\
\hline \\
$\begin{array}{c}\text { Total transferencia } \\
\text { cercana }=20,4\end{array}$ & \multicolumn{10}{c|}{ Total transferencia lejana $=79,6$} \\
\hline
\end{tabular}

Fuente: Elaboración propia.

Nota: a) procesamiento temporal y orientación de la atención en el tiempo, b) habilidades motoras finas, c) habilidades de escucha, d) memoria verbal, e) habilidades sociales, f) habilidades de escucha y lectura, g) funciones ejecutivas, h) IQ general, i) desempeño académico,j) creatividad, k) etnia, l) evidencia neurocientífica.

Como análisis final, se generó un gráfico comparativo para la transferencia cercana y lejana de lo que lleva transcurrido el siglo XXI, con líneas de tendencia para ambos tipos de transferencia (polinómicas), según la distribución de las 127 variables dependientes de los estudios revisados. El resultado se muestra en la Figura 1 (ver Figura 1). 


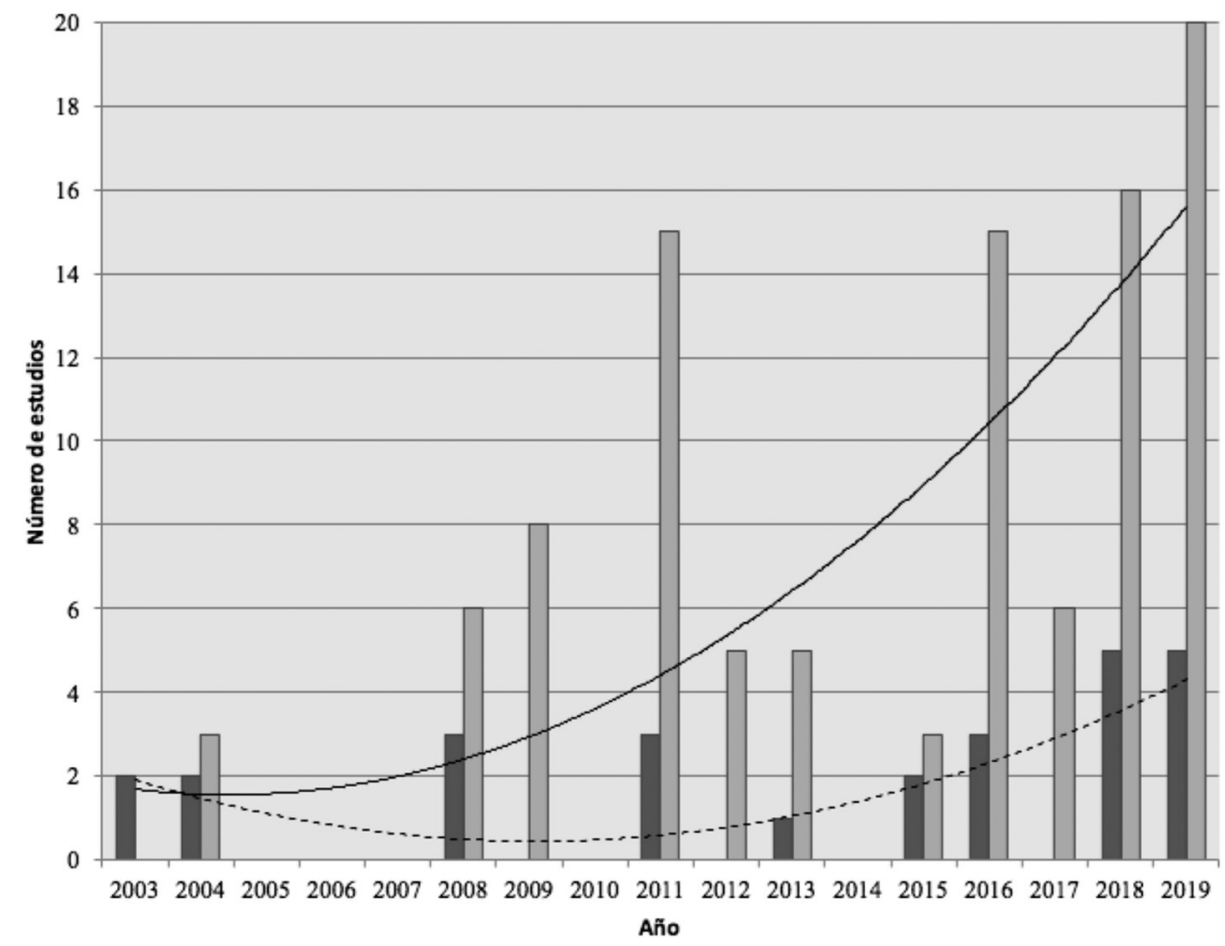

Figura 1: Distribución de variables dependientes por año, en estudios asociados a la música para transferencia cercana y lejana.

Fuente: Elaboración propia.

Leyenda:

$\square=$ Barras gris oscuro: estudios de transferencia cercana .

= Barras gris claro: estudios de transferencia lejana.

- = Línea punteada: tendencia polinómica para estudios de transferencia cercana, calculada a base de la siguiente fórmula: $\mathrm{y}=0,0393 \mathrm{x}^{2}-0,5587 \mathrm{x}-2,4265 . R^{2}=0,42043$

= Línea continua: tendencia polinómica para estudios de transferencia lejana, calculada a base de la siguiente fórmula: $\mathrm{y}=0,0662 \mathrm{x}^{2}-0,3211 \mathrm{x}+1,9412 . R^{2}=0,49117$

\section{DISCUSIÓN Y CONCLUSIONES}

Ciertamente, medir el impacto de la educación o el entrenamiento musical es tarea difícil, y la literatura no necesariamente responde a los tópicos cuando existe evidencia contraria o contradictoria. Para acercarse más a estas líneas de investigación, este estudio mostró las principales distribuciones que tienen las variables dependientes de 127 estudios, en la transferencia de habilidades cercanas y lejanas, otorgadas por la educación o entrenamiento musical en lo que va del siglo XXI. Los resultados muestran que hay un mayor porcentaje de estudios cuantitativos que se han acercado a la problemática, particularmente en niños y adultos de desarrollo típico, y con una tendencia a tomar el entrenamiento musical como la interpretación de un instrumento, y no desde una perspectiva integral.

En menor proporción se estima el entrenamiento musical como la apreciación u otras subáreas de la disciplina. Estos datos descriptivos muestran una imagen clara de las 
debilidades que la literatura ha dejado de lado, ya que, en investigaciones de este carácter, las poblaciones que podrían verse favorecidas por la educación o entrenamiento musical -como el desarrollo atípico (e.g. síndrome de Down o Williams) - no han sido recurrentemente contempladas, y probablemente se podrían mostrar hallazgos que favorecieran el entendimiento del ejercicio musical para personas con este tipo de desarrollo, en el rango etario que sea, tanto para transferencia cercana como lejana.

Como describen otros estudios, la evidencia sigue siendo contradictoria respecto de la transferencia de habilidades lejanas dadas por la educación o entrenamiento musical. Sin embargo, de manera natural en el siglo XXI, se han ido ampliando las investigaciones que abarquen esta problemática, existiendo desde principios de siglo hasta la fecha 79,6\% de literatura que asocia la música y transferencia de habilidades lejanas, característica que muestra un panorama favorable en el entendimiento del ejercicio musical y el efecto, impacto o alcance que tiene la música en el desarrollo humano fuera de la música, pese a que los metaanálisis tienden a subestimar los efectos en este tipo de variables (Sala y Gobet, 2017).

Como se nombró recientemente, debido a que en la transferencia de habilidades cercanas favorecidas por la música existen más certezas que preguntas, se torna razonable con estos datos proponer que la investigación en el área comience a indagar en población con desarrollo atípico. Quizá la literatura ha estado enfocada en responder la pregunta de si existe transferencia lejana o no en población de desarrollo típico, y desafortunadamente, este esfuerzo ha mermado el llevar la investigación a otros campos que en la actualidad se proponen relevantes en el mundo de la educación, como la inclusión y la diversidad.

Otra debilidad importante que muestran estos resultados es que los artículos que están escritos en español y que estudian este tipo de transferencia es muy bajo (un único artículo integra estos tópicos). A causa de que la mayoría de los estudios son cuantitativos, podría estar a la base que esos resultados se replicarían por ejemplo en población latinoamericana o chilena. Sin embargo, el hecho de que sean prácticamente inexistentes invalidaría ese supuesto, ya que no es observable. Esta debilidad es lamentable, ya que existen diversas iniciativas en Latinoamérica (e.g. la Orquesta de instrumentos reciclados de Cateura, o la Orquesta Alimenta una Esperanza Musical de Colombia), y en Chile (e.g. Orquesta Sinfónica Intercultural de Panguipulli, la Fundación de Orquestas Juveniles e Infantiles de Chile, o la Orquesta de la Fundación Cultural Papageno), que muestran a la música aportando de manera cualitativa al desarrollo de todos esos estudiantes en diversos ámbitos, pero con un bajo apoyo en términos de evidencia cuantitativa que pueda soportar esos datos. Hallazgos de esa naturaleza podrían servir no solo para mejorar aspectos de vida de cada lugar en particular, sino también, podrían influir en políticas públicas que integren más a la música en el quehacer diario de niños y niñas en Latinoamérica y Chile, en sectores donde existen las condiciones adecuadas para docentes y estudiantes, pero donde, a la fecha, no se aprecian políticas públicas regulares en el tiempo que afecten de manera directa este tipo de iniciativas.

Las líneas de tendencia que muestra el último análisis dan a conocer que, tanto para transferencia cercana como lejana, es probable que la cantidad de investigación siga un curso ascendente. Una forma de entender aún más el alcance de la música en general sería ampliar los puntos que aquí se plantean como debilidades, aunque desde otro punto de vista, es evidente que a principios de este siglo se inició una línea de investigación que ha mostrado hallazgos interesantes en estas conexiones, y que sería esperable y positivo que siga creciendo al paso que hasta el momento ha mostrado.

Se plantearon tres preguntas en el marco teórico. Respecto de la primera, con estos datos es razonable proponer que, pese a que con metaanálisis pareciera que la evidencia está sobreestimada, parece más difícil creer que la educación o el entrenamiento musical no generan nada en las personas, independiente de si es demostrable desde un punto de 
vista estadístico. Respecto de la segunda pregunta, habría que estudiar en detalle las causas que afectan las variables. Estudios longitudinales pueden satisfacer esta necesidad de la literatura. Por último, la evidencia neurocientífica también ha ido incrementándose en estos campos, por lo que plantear una conexión entre este tipo de hallazgos y las variables dependientes de los estudios pareciera ser cosa de tiempo.

De esta manera, el aporte de esta revisión bibliográfica va de la mano con dar a conocer las líneas de investigación que futuros estudios puedan abarcar, y así mostrar hallazgos que permitan seguir avanzando para las áreas de educación, ciencias sociales, u otras afines, tanto para la educación como para el entrenamiento musical.

\section{BIBLIOGRAFÍA}

Azaryahu, Libby, Susan Courey, Rivka Elkoshi, y Esther Adi-Japha

2019 "MusicMath" and "Academic Music" - Two music-based intervention programs for fractions learning in fourth grade students", Developmental Science, XXIII/4, e12882. DOI: 10.1111/ desc. 12882

Bakker, Arthur, Jinfa Cai, Lyn English, Gabriele Kaiser, Vilma Mesa, y Wim Van Dooren

2019 "Beyond small, medium, or large: points of consideration when interpreting effect sizes", Educational Studies in Mathematics, 102, pp. 1-8. ,DOI: 10.1007/s10649-019-09908-4

Barnett, Susan, y STEPhen Ceci

2002 "When and Where Do We Apply What We Learn? A Taxonomy for Far Transfer", Psychological Bulletin, CXXVIII/4, pp. 612-637. DOI: 10.1037//0033-2909.128.4.612

Bartolome, Sarah

2017 "Comparing Field-Teaching Experiences: A Longitudinal Examination of Preservice and First-Year Teacher Perspectives", Journal of Research in Music Education, LXV/3. pp. 264-286. DOI: $10.1177 / 0022429417730043$

Bedoin, Nathalie, Albert Besombes, Éliette Escande, Agathe Dumont, Philippe Lalitte, y Barbara TillmanN

2018 "Boosting syntax training with temporally regular musical primes in children with cochlear implants", Annals of Physical and Rehabilitation Medicine, LXI/6. pp. 365-371. DOI: 10.1016/j. rehab.2017.03.004

Beineke, Viviane, y Camila Zanetta

2014 “'Ou Isto ou Aquilo”: a Composição na Educação Musical para Crianças”, Revista Música Hodie, Goiânia, XIV/1, pp. 197-210. DOI: 10.5216/mh.v14i1.32978

Bidelman, Gavin, y Claude Alain

2015 "Musical Training Orchestrates Coordinated Neuroplasticity in Auditory Brainstem and Cortex to Counteract Age-Related Declines in Categorical Vowel Perception". The Journal of Neurosciences, XXXV/3, pp. 1240-1249. DOI: 10.1523/JNEUROSCI.3292-14.2015

Bier, Nathalie, Véronique Provencher, Lise Gagnon, Martial Van der Linden, Stéphane Adam, y JOHANNe DESROSIERS

2008 "New learning in dementia: Transfer and spontaneous use of learning in everyday life functioning. Two cases of studies", Neuropsychological Rehabilitation, XVIII/2, pp. 204-235. DOI: $10.1080 / 09602010701406581$

Binson-Sumrongthong, Bussakorn

2009 "Rites and Beliefs of Music in the Thailand's Lanna Region", Fontes Artis Musicae, LVI/3, pp. 299-313.

BODNAR, ERIN

2017 "The Effect of Intentional, Preplanned Movement on Novice Conductors' Gesture". Journal of Music Teacher Education, XXVI/3, pp. 38-50. DOI: 10.1177/1057083716644651 
Bonacina, Silvia, Alice Cancer, Pier Lanzi, María Lorusso, y Alessandro Antonietti

2015 "Improving reading skills in students with dyslexia: the efficacy of a sublexical training with rhythmic background", Frontiers in Psychology, 6, 1510. DOI: 10.3389/fpsyg.2015.01510

Blom, DiAna

2006 "Beyond the cover version: encouraging student performers to produce original interpretations of popular songs", International Journal of Music Education, XXIV/2, pp. 159-167. DOI: $10.1177 / 0255761406065477$

BROWN, JUDITH

2009 "Reflective practice: a tool for measuring the development of generic skills in the training of professional musicians", International Journal of Music Education, XXVII/4. pp. 372-382. DOI: $10.1177 / 0255761409345437$

Brown, Rachel, y Virginia Penhune

2018 "Efficacy of Auditory versus Motor Learning for Skilled and Novice Performers". Journal of Cognitive Neuroscience, XXX/11, pp. 1657-1682. DOI: 10.1162/jocn_a_01390

Busse, Vera, Jana Jungclaus, Ingo Roden, Frank Russo, y Gunter Kreutz

2018 "Combining Song-And Speech-Based Language Teaching: An Intervention With Recently Migrated Children”. Frontiers in Psychology, 9, 2386. DOI: 10.3389/fpsyg.2018.02386

Caramiaux, Baptiste, Frédéric Bevilacoua, Marcelo Wanderley, y Caroline Palmer

2018 "Dissociable effects of practice variability on learning motor and timing skills", PLoS ONE, XIII/3, e0193580. DOI: 10.1371/journal.pone.0193580

Carpentier, Sarah, Sylvain Moreno, y Anthony McIntosh

2016 "Short-term Music Training Enhances Complex, Distributed Neural Communication during Music and Linguistic Tasks", Journal of Cognitive Neurosciences, XXVIII/10, pp. 1603-1612. DOI: 10.1162/jocn_a_00988

Carrillo, Carmen, laia Viladot, y Jéssica Pérez-Moreno

2017 "Impacto de la educación musical: una revisión bibliográfica de la literatura científica", Revista Electrónica Complutense de Investigación en Educación Musical - RECIEM, 14, pp. 61-74. DOI: $10.5209 /$ RECIEM.54828

CHENG, JACK

2009 "A Review of Early Dynastic Iii Music: Man’s Animal Call”, Journal of Near Eastern Studies, LXVIII/3, pp. 163-178. DOI: 10.1086/613988

Chobert, Julie, Céline Marie, Clément François, Daniele Schön, Mireille Besson

2011 "Enhance Passive and Active Processing of Syllabes in Musician Children", Journal of Cognitive Neuroscience, XXIII/12, pp. 3874-3887. DOI: 10.1162/jocn_a_00088

Cohen, JaCoв

1988 Statistical Power Analysis for the Behavioral Sciences. 2a ed. Hillsdale, NJ: Erlbaum.

Cohrdes, Caroline, Lorenz Grolig, y Sascha Schroeder

2016 "Relating Language and Music Skills in Young Children: A First Approach to Systemize and Compare Distinct Competencies on Different Levels", Frontiers in Psychology, 7, 1616. DOI: 10.3389/fpsyg.2016.01616

CoOper, Shelly

2005 "Marguerite V. Hood and Music Education Radio Broadcasts in Rural Montana (1937-39)", Journal of Research in Music Education, LIII/4, pp. 295-307. DOI: 10.1177/002242940505300402

Corrigal, Kathleen, y Laurel Trainor

2011 "Associations Between Length of Music Training and Reading Skills in Children”, Music Perception, XXIX/2. pp. 147-155. DOI: 10.1525/mp.2011.20.2.147

DEEMER, RoB

2016 "Reimagining the Role of the Composition in Music Teacher Education", Music Educators Journal, CII/3, pp. 41-45. DOI: 10.1177/0027432115626253 
Degé, Franziska, y Gudrun Schwarzer

2018 "The influence of an extended music curriculum at school on academic self-concept in 9- to 11-year-old children”, Musicae Scientiae, XXII/3. pp. 305-321. DOI: 10.1177/1029864916688508

Esteve-Faubel, José-María, Jonathan Stephens, y Miguel Molina

2013 "A quantitative assessment of students' experiences of studying music: a Spanish perspective on the European credit transfer system (ECTS)", British Journal of Music Education, XXX/1. pp. 59-84. DOI: 10.1017/S0265051712000071

FLOYD, SAMUEL

1981 "Musical performance and scholarship in higher education". College Music Symposium, XXI/2, pp. 101-111.

Fuller, Christina, John Galvin, Bert MaAt, Deniz Baskent, y Rolien Free

2018 "Comparison of Two Music Training Approaches on Music and Speech Perception in Cochlear Implant Users”, Trends in Hearing, 22, pp. 1-22. DOI: 10.1177/2331216518765379

Furuya, Shinichi, Ayumi Nakamura, y Noriko Nagata

2013 "Transfer of piano practice in fast performance of skilled finger movements", BMC Neuroscience, XIV/1, article 133. DOI: 10.1186/1471-2202-14-133

Gomez-Dominguez, María, María-Carmen Fonseca-Mora, y Francisco Machancoses

2019 "First and foreign language early reading abilities: The influence of musical perception", Psychology of Music, XLVII/2, pp. 213-224. DOI: 10.1177/0305735617746734

GOODING, LORI

2011 "The Effect of Music Therapy Social Skills Training Program in Improving Social Competence in Children and Adolescents with Social Skills Deficits", Journal of Music Therapy, XLVIII/4. pp. 440-462. DOI: $10.1093 / \mathrm{jmt} / 48.4 .440$

Gromko, JoYce

2004 "Predictors of Music Sight-Reading Ability in High School Wind Players", Journal of Research in Music Education, LII/1. pp. 6-15. DOI: 10.2307/3345521

Harrison, Clive

2016 "Bebop on the Hockey Pitch: Cross-Disciplinary Creativity and Skills Transfer", Frontiers in Psychology, 9, 123. DOI: 10.3389/fpsyg.2016.00123

Heunis, Daniela

2013 “Active improvisation In The Classroom: Dalcroze, Kodály, And Orff. Orff”. Echo, XLV/2, pp. 32-35.

Hughes, Alayna

2018 "Maker music: Incorporating the maker and hacker community into music technology education", Journal of Music, Technology $\mathcal{E}$ Education, XI/3, pp. 287-300. DOI: 10.1386/ jmte.11.3.287_1

Hutchins, SEAN

2018 "Early childhood music training and associated improvements in music and language abilities”, Music Perception, XXXV/5, pp. 579-593. DOI: 10.1525/mp.2018.35.5.579

Jaschke, Artur, HenkJan Honing, y Erik Scherder

2018 "Longitudinal Analysis of Music Education on Executive Functions in Primary School Children", Frontiers in Neurosciences, 12, 103. DOI: 10.3389/fnins.2018.00103

Larrouy-Maestri, Pauline, Jacqueline Leybaert, y Regine Kolinsky

2013 "The benefit of musical and linguistic expertise on language acquisition in sung material", Musicae Scientiae, XVII/2. pp. 217-228. DOI: 10.1177/1029864912473470

LATIMER, MARVin

2018 "Excellence in Choral Music: A Chronology of the American Choral Directors Association", Choral Journal, LIX/2, pp. 37-45. 
Loehr, Janeen, y Cordula Vesper

2016 "The sound of you and me: Novices represent shared goals in joint action", The Quarterly Journal of Experimental Psychology, LXIX/3, pp. 535-547. DOI: 10.1080/17470218.2015.1061029

LukÁcs, Borbála, y Ferenc Honbolygó

2019 "Task-Dependent Mechanisms in the Perception of Music and Speech: Domain-Specific Transfer Effects of Elementary School Music Education", Journal of Research in Music Education, LXVII/2, pp. 153-170. DOI: 10.1177/0022429419836422

Maróti, Emese, Edirna Barabás, Gabriella Deszpot, Tamara Farnadi, Lászlo Norbert, Borbála SZIRÁNYi, y FERENC HoNBOLYGó

2019 "Does moving to the music make you smarter? The relation of sensimotor entrainment to cognitive, linguistic, musical, and social skills", Psychology of Music, XLVII/5, pp. 663-679. DOI: $10.1177 / 0305735618778765$

Medina, David, y Paulo Barraza

2019 "Efficiency of attentional networks in musicians and non-musicians", Heliyon, V/3, e01315. DOI: 10.1016/j.heliyon.2019.e01315

Menezes, Mara, y Zuraida Abud

2016 "Developing Listening Skills in the Primary School through Expressive Music Appreciation", Problems in Music Pedagogy, XV/2, pp. 39-46.

Meyer, Rosalee, y Caroline Palmer

2003 "Temporal and Motor Transfer in Music Performance", Music Perception, XXI/1. pp. 81-104, DOI: $10.1525 / \mathrm{mp} .2003 .21 .1 .81$

Miendlarzewska, Ewa, y Wiebre Trost

2014 "How musical training affects cognitive development: rhythm, reward and other modulating variables", Frontiers in Neurosciences, 7, 79. DOI: 10.3389/fnins.2013.00279

Möhring, Wenke, Kizzann Ramsook, Kathy Hirsch-Pasek, Roberta Golinkoff, y Nora Newcombe 2016 "Where music meets space: Children's sensitivity to pitch intervals is related to their mental spatial transformation skills", Cognition, 151, pp. 1-5. DOI: 10.1016/j.cognition.2016.02.016

Moreno, Sylvain, Ellen Bialystok, Raluca Barac, E. Glenn Schellenberg, Nicholas Cepeda, Y TOM CHAU

2011 "Short-term Music Training Enhances Verbal Intelligence and Executive Function", Psychological Sciences, XXII/11, pp. 1425-1433. DOI: 10.1177/0956797611416999

Muthivhi, Azwihangwisi, y Samantha Kriger

2019 "Music instruction and reading performance: Conceptual transfer in learning and development”, South African Journal of Childhood Education, IX/1, a544. DOI: 10.4102/sajce.v9i1.544

Nan, Yun, Li Liu, Eveline Geiser, Hua Shu, Chen Chen Gong, Qi Dong, John Gabrielli, y Robert DEsIMORE

2018 "Piano training enhances the neural processing of pitch and improves speech perception in Mandarin-speaking children", Proceedings of the National Academy of Sciences of the United States of America, CXV/28, E6630-6639. DOI: 10.1073/pnas.1808412115

Nethsinghe, Rohan

2012 "Finding balance in a mix of culture: Appreciation of diversity through multicultural music education”, International Journal of Music Education, XXX/4, pp. 382-396. DOI: $10.1177 / 0255761412459166$

Porflitt, Felipe, y Ricardo Rosas

2019 "Behind the scene: cognitive benefits of playing a musical instrument. Executive functions, processing speed, fluid intelligence and divided attention / Detrás de la escena: beneficios cognitivos de tocar un instrumento musical. Funciones ejecutivas, velocidad de procesamiento, inteligencia fluida y atención dividida”, Estudios de Psicología, XL/2, pp. 464-490. DOI: $10.1080 / 02109395.2019 .1601474$ 
2020a "Core music elements: rhythmic, melodic and harmonic musicians show differences in cognitive performance (Elementos básicos de la música: músicos rítmicos, melódicos y armónicos muestran diferencias de desempeño cognitivo)”. Estudios de Psicología, XLI/3, pp. 532-562. DOI: 10.1080/02109395.2020.1795493

$2020 \mathrm{~b} \quad$ "Musical sophistication explains a good deal of cognitive performance. A cross-sectional study of musicians and non-musicians", Resonancias, XXIV/47, pp. 147-167. DOI: 10.7764/ res.2020.47.9

Putkinen, Vesa, Minna Huotilainen, y Mari Tervaniemi

2019 "Neural Encoding of Pitch Direction Is Enhanced in Musically Trained Children and Is Related to Reading Skills", Frontiers in Psychology, 10, 1475. DOI: 10.3389/fpsyg.2019.01475

Rickard, Nikki, Caroline Bambrick, y Anneliese Gill

2012 "Absence of widespread psychological and cognitive effects of school-based music instruction in 10-13-year-old students", International Journal of Music Education, XXX/1. pp. 57-78. DOI: $10.1177 / 0255761411431399$

Roman, Stephane, Francoise Rochette, Jean-Michel Triglia, Daniele Schön, y Emmanuel Bigand 2016 "Auditory training improves auditory performance in cochlear implanted children", Hearing Research, 337, pp. 89-95. DOI: 10.1016/j.heares.2016.05.003

Rose, Dawn, Alice Bartoli, y Pamela Heaton

2019 "Measuring the impact of musical training on cognitive, behavioural and socio-emotional wellbeing development in children”, Psychology of Music, XLVII/2, pp. 284-303. DOI: $10.1177 / 0305735617744887$

Sadakata, Makiko, David Hoppe, Alex Brandmeyer, Renee Timmers, y Peter Desain

2008 "Real-Time Visual Feedback for Learning to Perform Short Rhythms with Expressive Variations in Timing and Loudness", Journal of New Music Research, XXXVII/3, pp. 207-220. DOI: $10.1080 / 09298210802322401$

Sala, Giovanni, Nazli Denis, Semir Tatlidil, Tomoko Tatsumi, Yasuyuki Gondo, Fernand Gobet 2019 "Near and Far Transfer in Cognitive Training: A Second-Order Meta-Analysis", Collabra: Psychology, V/1, pp. 18-22. DOI: 10.1525/collabra.203

Sala, Giovanni, y Fernand Gobet

2017 "Does Far Transfer Exist? Negative Evidence From Chess, Music, and Working Memory Training”, Current Directions in Psychological Science, XXVI/6, pp. 515-520. DOI: $10.1177 / 0963721417712760$

Schellenberg, E. GlenN

2004 “Music Lessons Enhance IQ", Psychological Sciences, XV/8, pp. 511-514. DOI: 10.1111/j.0956-7976.2004.00711.x

2006 "Long-Term Positive Associations Between Music Lessons and IQ", Journal of Educational Psychology, XCVIII/2. pp. 457-468. DOI: 10.1037/0022-0663.98.2.457

2011 "Examining the association between music lessons and intelligence", British Journal of Psychology, CII/3. pp. 283-302. DOI: 10.1111/j.2044-8295.2010.02000.x

SEIDL, VERENA

2011 "Musikalische Bildung - Ansprüche und Wirklichkeiten. Reflexionen aus Musikwissenschaft und Musikpädagogik", Musikforschung, LXIV/4, pp. 390-391. 
Silveira, JASON

2014 "The Perception of Pacing in a Music Appreciation Class and Its Relationship to Teacher Effectiveness and Teacher Intensity", Journal of Research in Music Education, LXII/3, pp. 302 318. DOI: $10.1177 / 0022429414542978$

Singley, MARK, y JOHN ANDERSON

1989 The transfer of cognitive skill. Cambridge, MA: Harvard University Press.

Swaminathan, Swathi, y E. Glenn Schellenberg

2017 "Musical competence and phoneme perception in a foreign language", Psychonomic Bulletin Ẽ Review, XXIV/6, pp. 1929-1934. DOI: 10.3758/s13423-017-1244-5

TAatgen, Niels

2013 "The nature and transfer of cognitive skills", Psychological Review, 120, pp. 439-471. DOI: $10.1037 / \mathrm{a} 0033138$

ThORndike, EdWARd, \& Robert WOODWORTH

1901 "The influence of improvement in one mental function upon the efficiency of other functions. (I)", Psychological Review, 8, pp. 247-261. DOI: 10.1037/h0071280

Toulson, Rob, y Russ HePwOrTh-SAwYer

2018 "Connected learning journeys in music production education", Journal of Music, Technology Eं Education, XI/3, pp. 269-286. DOI: 10.1386/jmte.11.3.269_1

VAlerio, Wendy, y Nancy Freeman

2009 "Pre-Service Teachers' Perceptions of Early Childhood Music Teaching Experiences", Bulletin of the Council for Research in Music Education, 181, pp. 51-69.

VAN Vugt, Flois, y Barbara Tillmann

2015 "Auditory feedback in error-based learning of motor regularity", Brain Research, 1606, pp. 54-67. DOI: 10.1016/j.brainres.2015.02.026

van Westrhenena, Nadine, y Elzette Fritz

2013 "The experiences of professional hospice workers attending creative arts workshops in Gauteng”, Health Education Journal, LXXII/1, pp. 34-46. DOI: 10.1177/0017896911430545

WADE, RALPH

1975 "Susanne K. Langer's musical aesthetics with implications for music education", Journal of the Indian Musicological Society, VI/2, pp. 5-26.

Zheng, Yi, y ArThur SAMUEL

2018 "The effects of ethnicity, musicianship, and tone language experience on pitch perception", Quarterly Journal of Experimental Psychology, LXXI/12, pp. 2627-2642. DOI: $10.1177 / 1747021818757435$ 


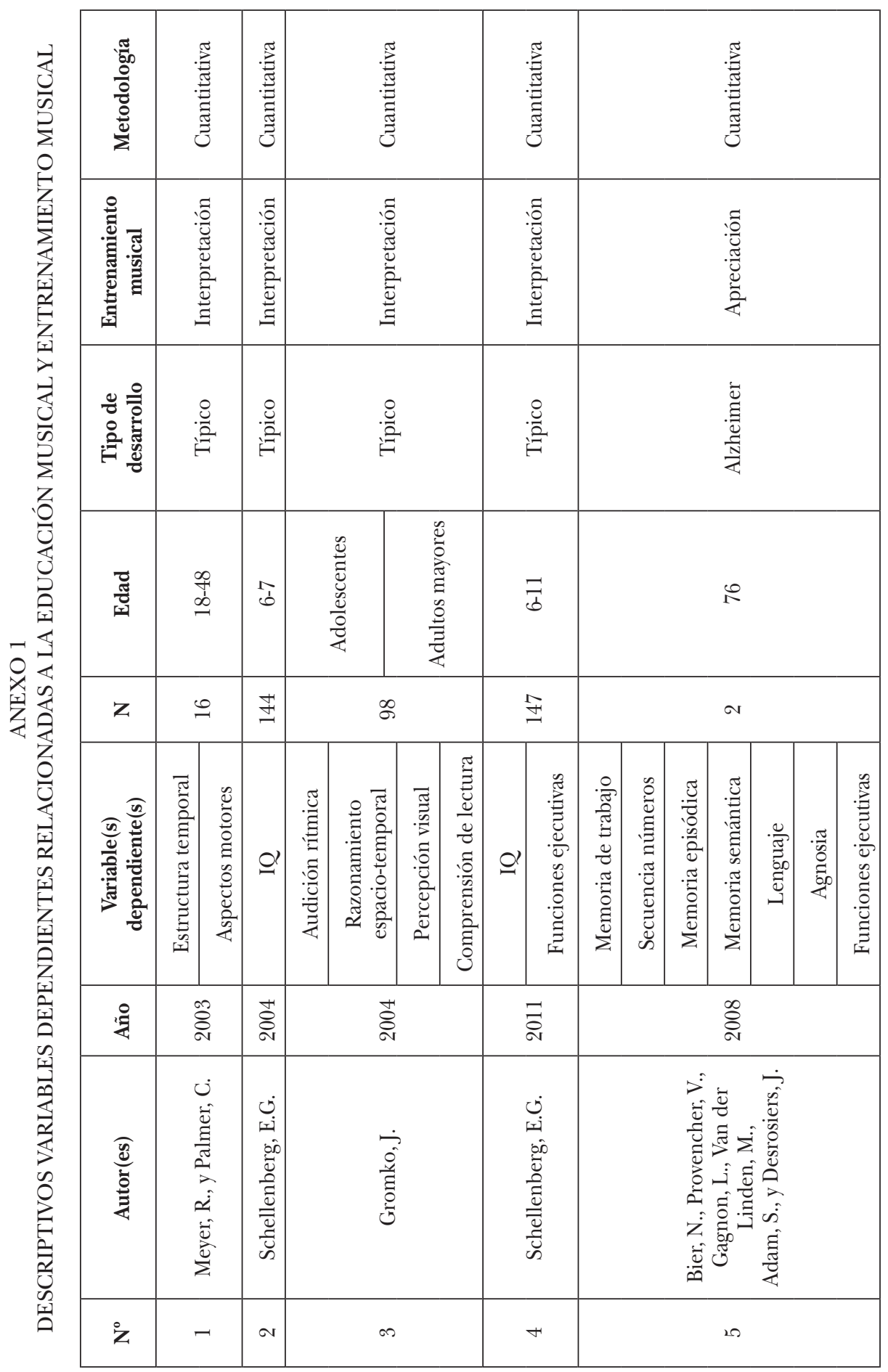




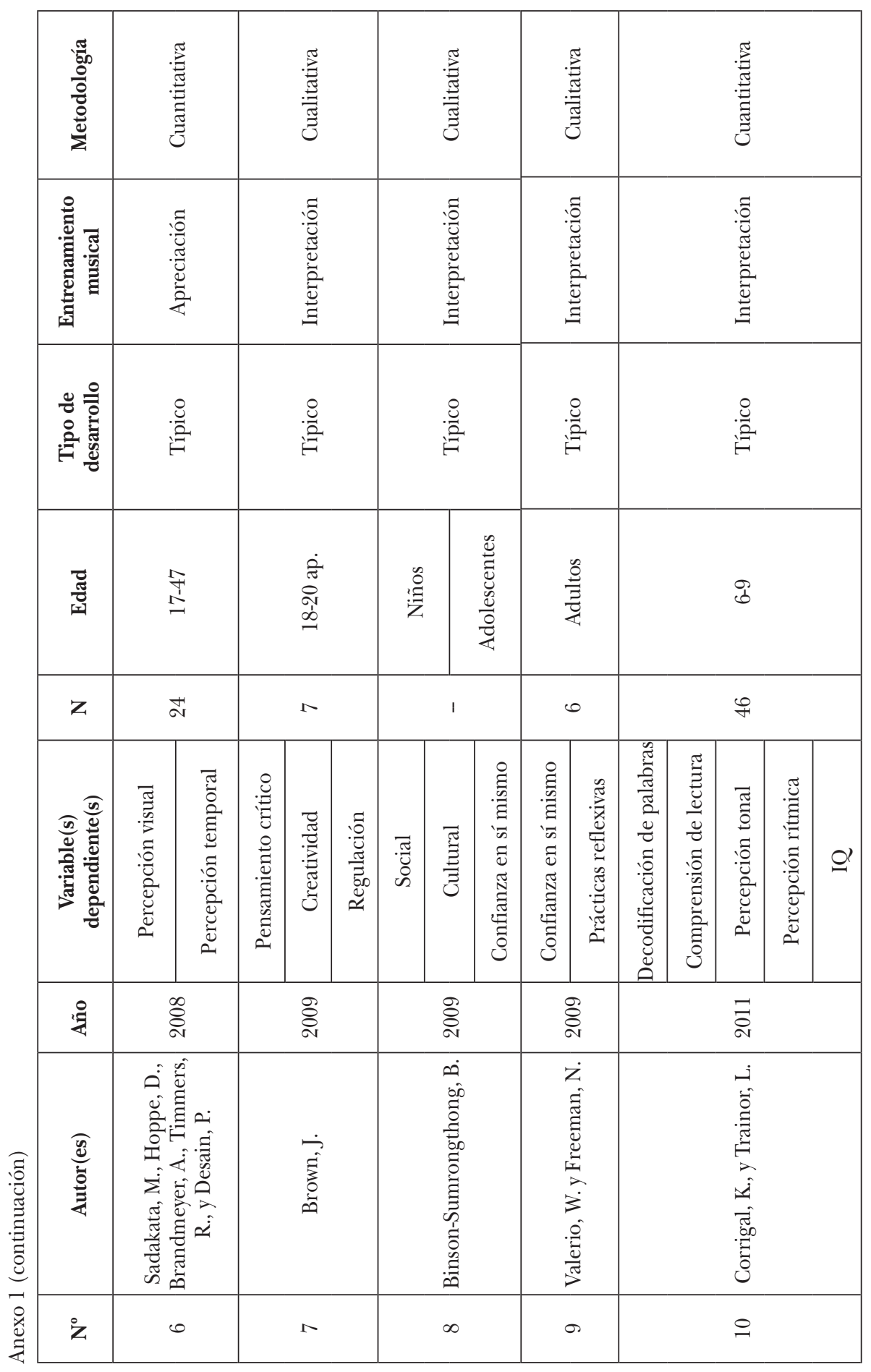




\begin{tabular}{|c|c|c|c|c|c|c|c|c|c|c|c|c|c|c|c|c|}
\hline 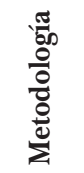 & 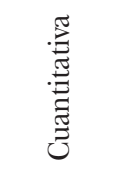 & & & 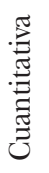 & & & & 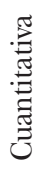 & & & כ. & \multicolumn{5}{|c|}{ 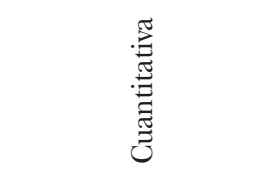 } \\
\hline 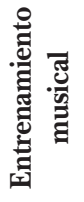 & 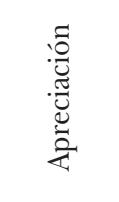 & \multicolumn{5}{|c|}{ 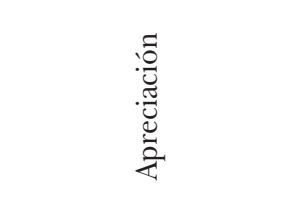 } & \multicolumn{3}{|c|}{ 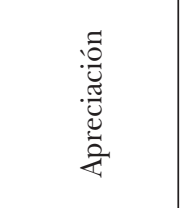 } & \multicolumn{2}{|c|}{ 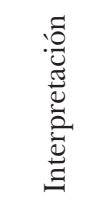 } & \multicolumn{5}{|c|}{ 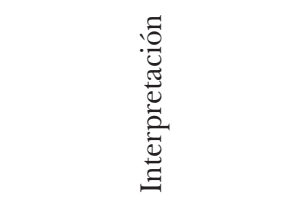 } \\
\hline 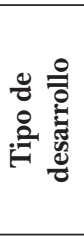 & 总 & $\begin{array}{l}\tilde{u} \\
\stackrel{0}{0} \\
\infty\end{array}$ & 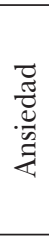 & & 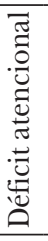 & & & \multicolumn{2}{|l|}{ 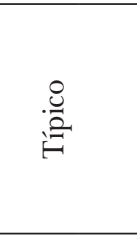 } & \multicolumn{2}{|c|}{ 总 } & \multicolumn{5}{|c|}{ 总 } \\
\hline ర్ & $\stackrel{\circ}{\circ}$ & \multicolumn{5}{|c|}{ 긍 } & \multicolumn{3}{|c|}{$\stackrel{q}{q}$} & \multicolumn{2}{|c|}{$\frac{\text { जे }}{\sigma}$} & \multicolumn{5}{|c|}{$\frac{m}{b}$} \\
\hline z & $\stackrel{\infty}{\sim}$ & \multicolumn{5}{|c|}{19} & \multicolumn{3}{|c|}{$\stackrel{\infty}{+}$} & & & \multicolumn{5}{|c|}{$\Xi$} \\
\hline 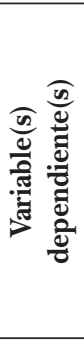 & 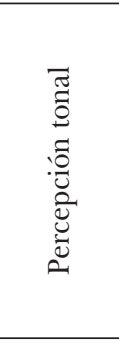 & 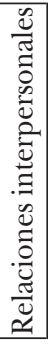 & 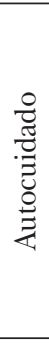 & 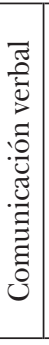 & 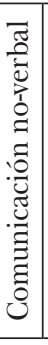 & 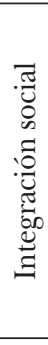 & 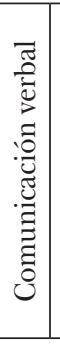 & 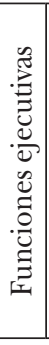 & 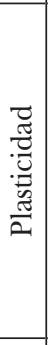 & $\varrho$ & 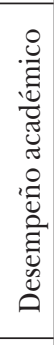 & 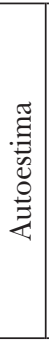 & 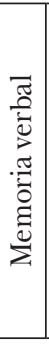 & 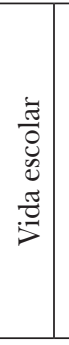 & 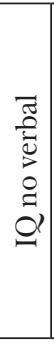 & 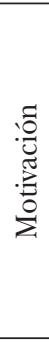 \\
\hline 究 & $\overrightarrow{\vec{a}}$ & \multicolumn{5}{|c|}{$\overrightarrow{\vec{\Xi}}$} & \multicolumn{3}{|c|}{$\overrightarrow{\text { ㄱ }}$} & & tiv & \multicolumn{5}{|c|}{$\begin{array}{l}\stackrel{v}{*} \\
\stackrel{\sim}{\sim}\end{array}$} \\
\hline & 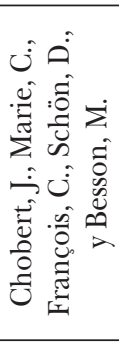 & \multicolumn{5}{|c|}{ 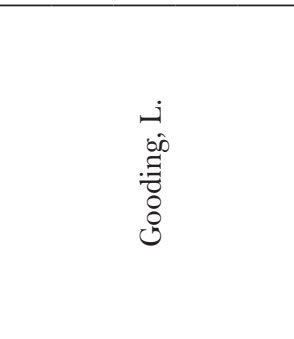 } & \multicolumn{3}{|c|}{ 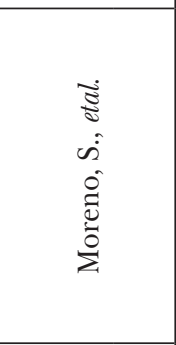 } & & 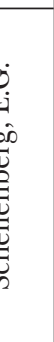 & \multicolumn{5}{|c|}{ 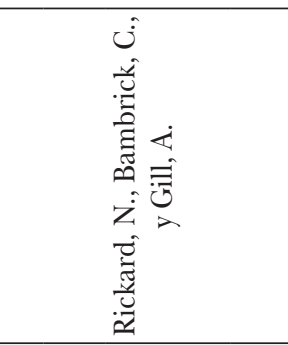 } \\
\hline ¿ & $=$ & \multicolumn{5}{|c|}{$\cong$} & \multicolumn{3}{|c|}{$\stackrel{2}{2}$} & & $t$ & \multicolumn{5}{|c|}{20} \\
\hline
\end{tabular}




\begin{tabular}{|c|c|c|c|c|c|c|c|c|c|c|c|}
\hline $\begin{array}{l}\text { 苟 } \\
\frac{0}{0} \\
\frac{0}{0} \\
\frac{0}{0}\end{array}$ & 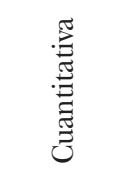 & 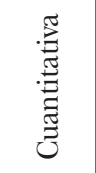 & 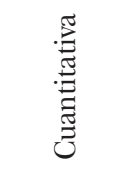 & \multicolumn{3}{|c|}{ 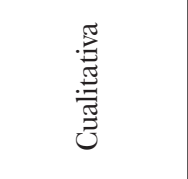 } & \multicolumn{2}{|c|}{ 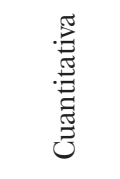 } & \multicolumn{2}{|c|}{ 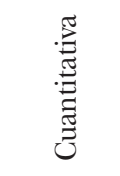 } & \multirow{2}{*}{ 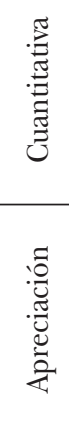 } \\
\hline 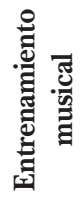 & 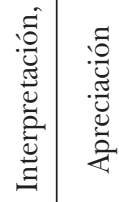 & 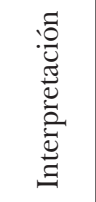 & 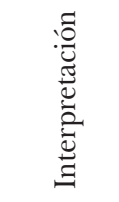 & \multicolumn{3}{|c|}{ 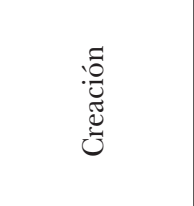 } & \multicolumn{2}{|c|}{ 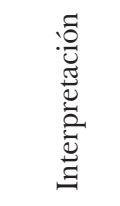 } & \multicolumn{2}{|c|}{ 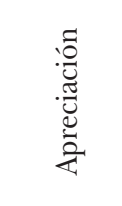 } & \\
\hline 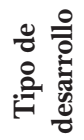 & 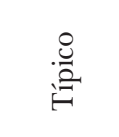 & 象 & 总 & \multicolumn{3}{|c|}{ 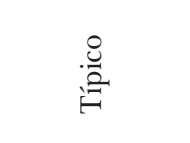 } & \multicolumn{2}{|c|}{ 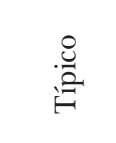 } & \multicolumn{2}{|c|}{ 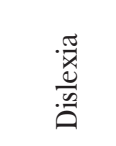 } & 苛 \\
\hline 点 & 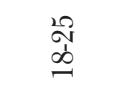 & $\begin{array}{l}\vec{y} \\
\text { d } \\
\text { d }\end{array}$ & 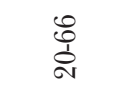 & \multicolumn{3}{|c|}{$\begin{array}{l}\stackrel{v}{0} \\
\stackrel{1}{a}\end{array}$} & \multicolumn{2}{|c|}{ 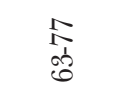 } & \multicolumn{2}{|c|}{$\stackrel{\uplus}{\Xi}$} & $\begin{array}{l}\text { के } \\
\text { ᄋे }\end{array}$ \\
\hline Z & 尽 & $\stackrel{\sim}{\sim}$ & $\stackrel{\infty}{+}$ & \multicolumn{3}{|c|}{$\stackrel{\theta}{\circ}$} & \multicolumn{2}{|c|}{ ฉ } & \multicolumn{2}{|c|}{$\stackrel{\infty}{\sim}$} & ది \\
\hline 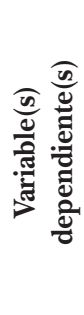 & 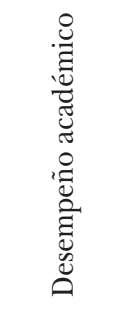 & 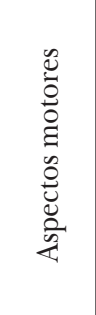 & 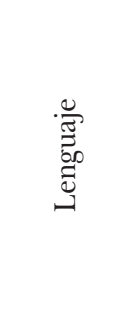 & 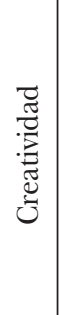 & 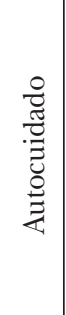 & 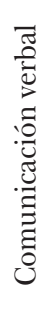 & 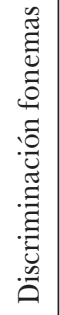 & 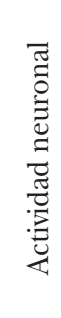 & $\stackrel{\widetilde{J}}{\stackrel{\widetilde{U}}{\mathcal{U}}}$ & 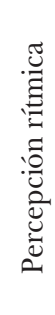 & 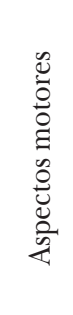 \\
\hline 完 & $\stackrel{\infty}{\stackrel{\infty}{2}}$ & $\stackrel{\infty}{\stackrel{\sim}{*}}$ & $\stackrel{\infty}{\stackrel{\sim}{*}}$ & \multicolumn{3}{|c|}{$\stackrel{\infty}{\stackrel{\sim}{\sigma}}$} & & $\overbrace{N}^{2}$ & \multicolumn{2}{|c|}{$\stackrel{10}{\stackrel{2}{\circ}}$} & $\begin{array}{l}\stackrel{20}{\vec{\sigma}} \\
\stackrel{2}{2}\end{array}$ \\
\hline 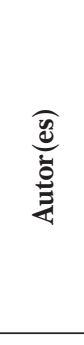 & 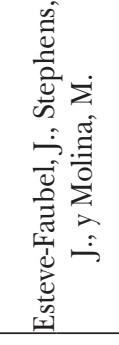 & 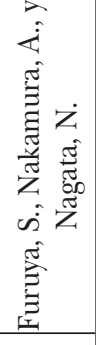 & 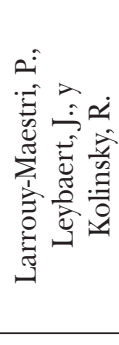 & \multicolumn{3}{|c|}{ 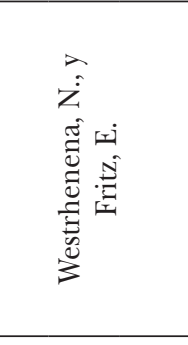 } & 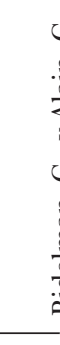 & 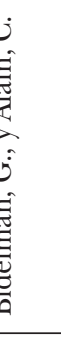 & \multicolumn{2}{|c|}{ 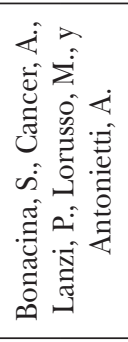 } & 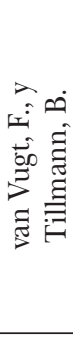 \\
\hline 号 & $\mathscr{\theta}$ & ㄱ & $\stackrel{\infty}{\sim}$ & \multicolumn{3}{|c|}{$\stackrel{\theta}{\Omega}$} & 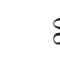 & $\vec{N}$ & \multicolumn{2}{|c|}{$\vec{a}$} & ฟั \\
\hline
\end{tabular}




\begin{tabular}{|c|c|c|c|c|c|c|c|c|c|c|c|c|}
\hline $\begin{array}{l}\frac{\pi}{60} \\
\frac{0}{0} \\
\frac{0}{0} \\
\frac{0}{0} \\
\frac{0}{2}\end{array}$ & & & \multicolumn{8}{|c|}{ 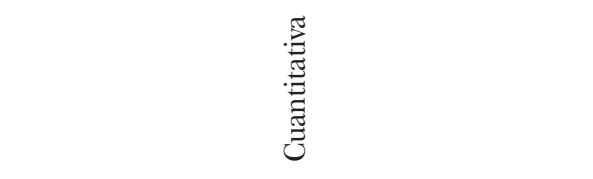 } & 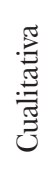 & 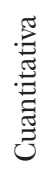 \\
\hline 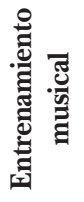 & & & \multicolumn{8}{|c|}{ 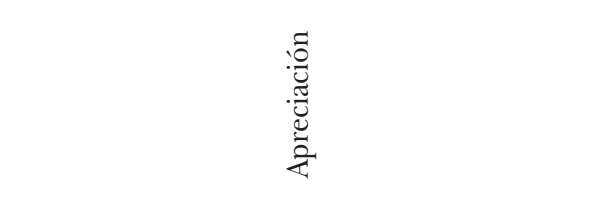 } & 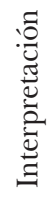 & 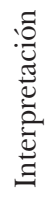 \\
\hline 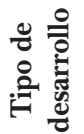 & & & \multicolumn{8}{|c|}{ 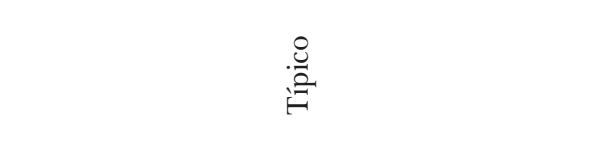 } & 蒿 & 葶 \\
\hline 宽 & & & \multicolumn{8}{|c|}{ 官 } & $\frac{\rho}{3}$ & $\begin{array}{l}\text { के } \\
\text { b }\end{array}$ \\
\hline Z & \multicolumn{2}{|c|}{ क } & \multicolumn{8}{|c|}{ 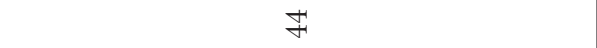 } & - & ๙े \\
\hline 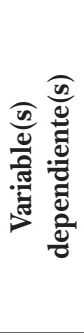 & 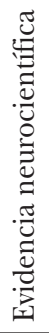 & 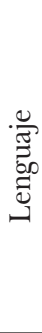 & 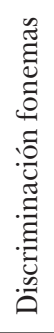 & 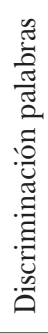 & 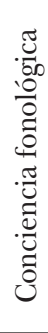 & 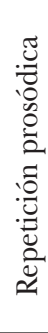 & 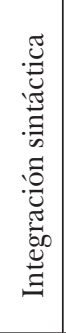 & 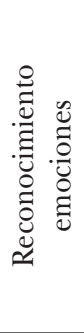 & 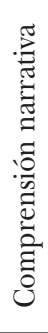 & 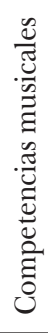 & 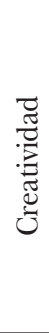 & 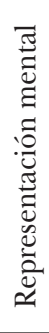 \\
\hline 宗 & \multicolumn{2}{|c|}{$\begin{array}{l}0 \\
\stackrel{0}{0} \\
\text { V }\end{array}$} & \multicolumn{8}{|c|}{$\begin{array}{c}\stackrel{0}{*} \\
\stackrel{\sim}{\circ}\end{array}$} & 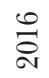 & $\stackrel{\circ}{\stackrel{\circ}{\sigma}}$ \\
\hline 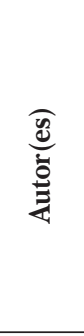 & \multicolumn{2}{|c|}{ 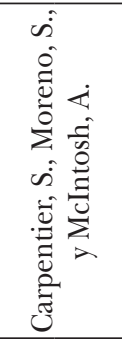 } & \multicolumn{8}{|c|}{ 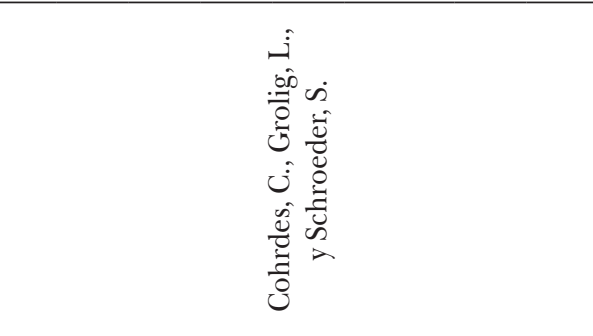 } & 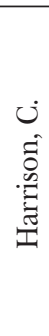 & 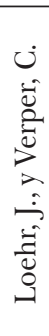 \\
\hline 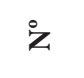 & \multicolumn{2}{|c|}{$\ddot{v}$} & \multicolumn{8}{|c|}{ ar } & $\stackrel{10}{\sigma}$ & $\mathscr{v}$ \\
\hline
\end{tabular}




\begin{tabular}{|c|c|c|c|c|c|c|c|c|c|c|c|c|c|}
\hline 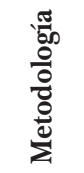 & \multicolumn{5}{|c|}{ 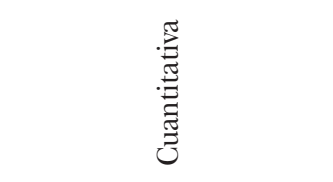 } & & & \multicolumn{3}{|c|}{ : } & \multicolumn{3}{|c|}{ 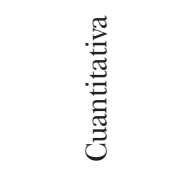 } \\
\hline 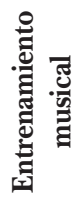 & \multicolumn{5}{|c|}{ 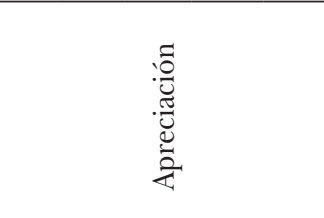 } & & & \multicolumn{3}{|c|}{ 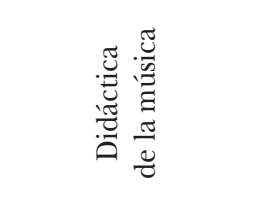 } & \multicolumn{3}{|c|}{ 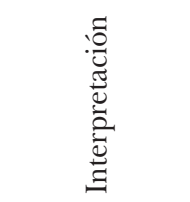 } \\
\hline 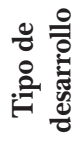 & \multicolumn{5}{|c|}{ 承 } & $\begin{array}{l}\stackrel{\Xi}{\Xi} \\
\stackrel{\Xi}{\Xi} \\
\stackrel{\Xi}{\Xi}\end{array}$ & $\begin{array}{l}\frac{0}{\tilde{J}} \\
\frac{\tilde{U}}{\tilde{U}} \\
0\end{array}$ & \multicolumn{3}{|c|}{ 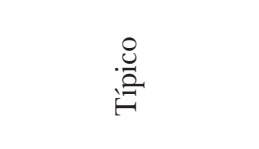 } & \multicolumn{3}{|c|}{ 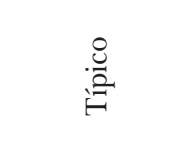 } \\
\hline 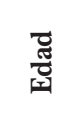 & \multicolumn{5}{|c|}{ 1) } & \multicolumn{2}{|c|}{$\frac{O}{4}$} & \multicolumn{3}{|c|}{$\frac{\stackrel{0}{G}}{\frac{3}{2}}$} & \multicolumn{3}{|c|}{$\stackrel{\circ}{\stackrel{D}{1}}$} \\
\hline Z & \multicolumn{5}{|c|}{8} & \multicolumn{2}{|c|}{$\stackrel{\theta}{\theta}$} & \multicolumn{3}{|c|}{ 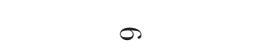 } & \multicolumn{3}{|c|}{$\sqrt{2}$} \\
\hline 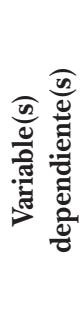 & 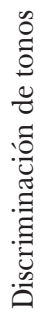 & 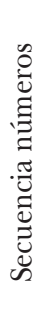 & 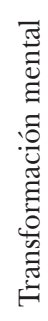 & 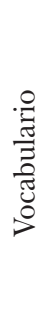 & 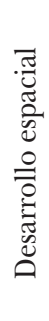 & 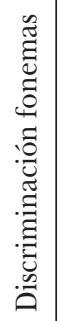 & $\begin{array}{l}. \frac{\pi}{0} \\
\stackrel{0}{0} \\
\sum_{0}^{0}\end{array}$ & 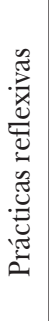 & 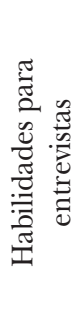 & 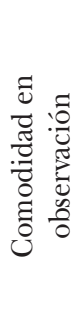 & 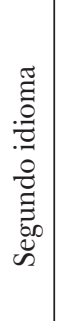 & 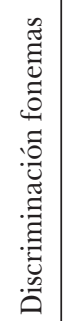 & 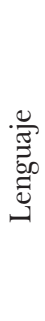 \\
\hline 宗 & \multicolumn{5}{|c|}{$\stackrel{\bullet}{\stackrel{\circ}{\sigma}}$} & \multicolumn{2}{|c|}{$\begin{array}{l}\stackrel{\bullet}{*} \\
\stackrel{\sim}{*}\end{array}$} & \multicolumn{3}{|c|}{$\stackrel{\vec{a}}{\vec{\sigma}}$} & \multicolumn{3}{|c|}{$\stackrel{\sim}{\stackrel{\circ}{\sigma}}$} \\
\hline 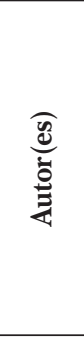 & \multicolumn{5}{|c|}{ 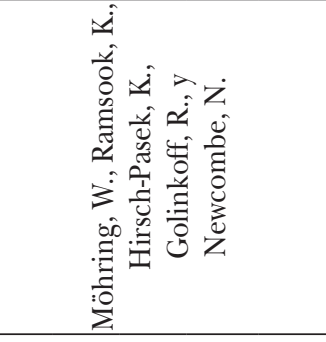 } & \multicolumn{2}{|c|}{ 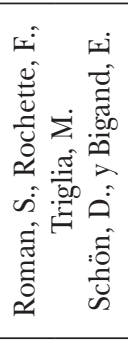 } & \multicolumn{3}{|c|}{ 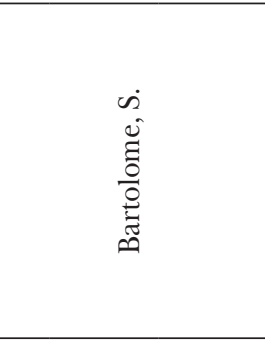 } & \multicolumn{3}{|c|}{ 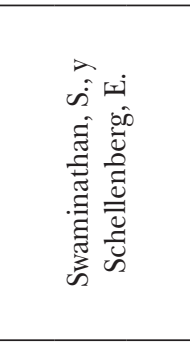 } \\
\hline ¿ & \multicolumn{5}{|c|}{ ลे } & 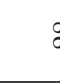 & & \multicolumn{3}{|c|}{$\stackrel{\sim}{ }$} & \multicolumn{3}{|c|}{ के } \\
\hline
\end{tabular}




\begin{tabular}{|c|c|c|c|c|c|c|c|c|c|c|c|c|c|}
\hline $\begin{array}{l}\frac{\pi}{60} \\
\frac{0}{0} \\
\frac{0}{0} \\
\stackrel{0}{0}\end{array}$ & \multicolumn{3}{|c|}{ 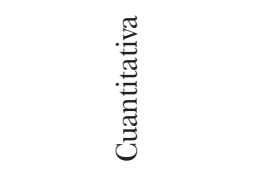 } & 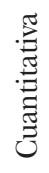 & 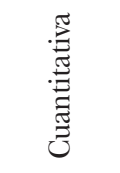 & \multicolumn{2}{|c|}{ 莺 } & 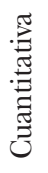 & \multicolumn{2}{|c|}{ 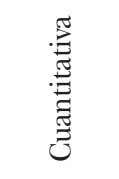 } & \multicolumn{3}{|c|}{ 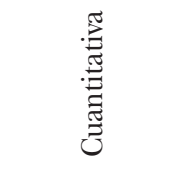 } \\
\hline 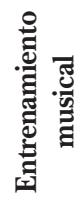 & \multicolumn{3}{|c|}{ 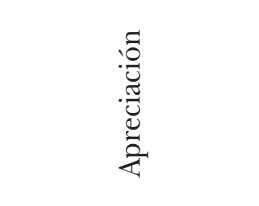 } & 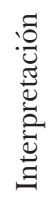 & 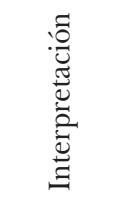 & \multicolumn{2}{|c|}{ 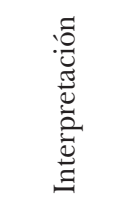 } & 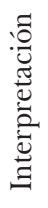 & 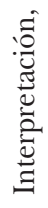 & 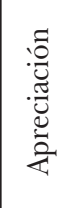 & \multicolumn{3}{|c|}{ 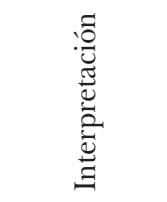 } \\
\hline 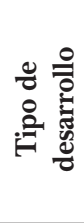 & & & 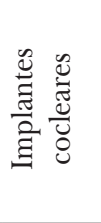 & $\begin{array}{l}\stackrel{\vartheta}{\mathscr{n}} \\
\text { 汽 }\end{array}$ & 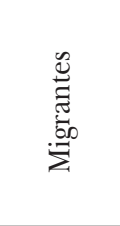 & & & 总 & $\frac{\stackrel{\mathscr{U}}{\Xi}}{\frac{\tilde{\Xi}}{\Xi}}$ & $\frac{\mathscr{U}}{\tilde{U}}$ & & 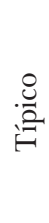 & \\
\hline 苞 & \multicolumn{3}{|c|}{$\begin{array}{l}\infty \\
1 \\
1\end{array}$} & $\begin{array}{l}\dot{a} \\
\text { aे } \\
\sigma \\
\text { dे }\end{array}$ & $\bar{b}$ & \multicolumn{2}{|c|}{$\begin{array}{l}\text { के } \\
\text { क }\end{array}$} & $\bar{\sigma}$ & \multicolumn{2}{|c|}{$\begin{array}{l}8 \\
0 \\
10 \\
10\end{array}$} & \multicolumn{3}{|c|}{ कै } \\
\hline z & \multicolumn{3}{|c|}{$\stackrel{0}{0}$} & ซิ & in & \multicolumn{2}{|c|}{$\stackrel{\infty}{+}$} & के & \multicolumn{2}{|c|}{$\stackrel{\theta}{2}$} & \multicolumn{3}{|c|}{$\&$} \\
\hline 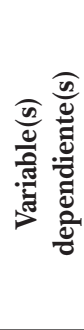 & 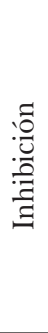 & & 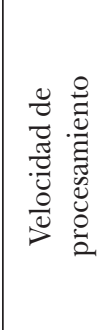 & 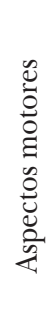 & 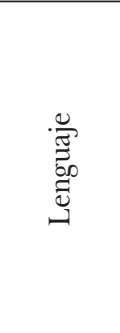 & 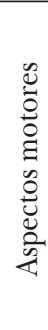 & 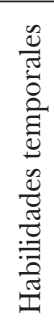 & 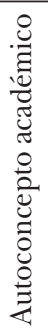 & 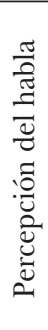 & 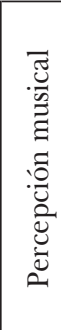 & 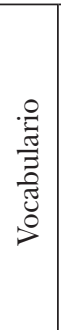 & 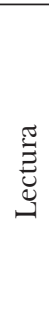 & 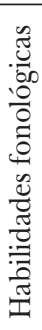 \\
\hline 宗 & \multicolumn{3}{|c|}{$\stackrel{\infty}{\stackrel{\infty}{*}}$} & $\stackrel{\infty}{\stackrel{\infty}{\circ}}$ & $\stackrel{\infty}{\stackrel{\infty}{\sigma}}$ & \multicolumn{2}{|c|}{$\stackrel{\infty}{\stackrel{2}{\sigma}}$} & $\stackrel{\infty}{\stackrel{\infty}{*}}$ & \multicolumn{2}{|c|}{$\stackrel{\infty}{\stackrel{\sim}{\sim}}$} & \multicolumn{3}{|c|}{$\stackrel{\infty}{\stackrel{\infty}{*}}$} \\
\hline 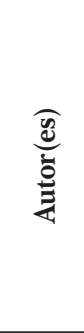 & \multicolumn{3}{|c|}{ 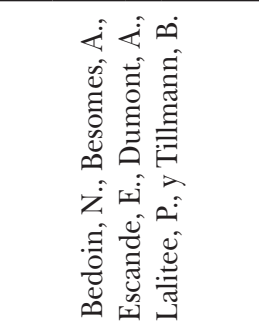 } & 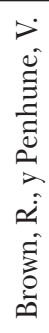 & 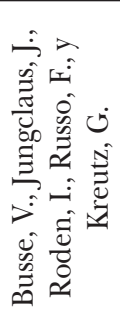 & \multicolumn{2}{|c|}{ 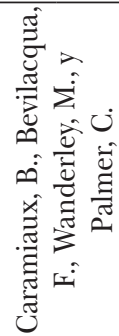 } & 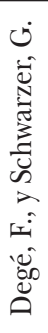 & \multicolumn{2}{|c|}{ 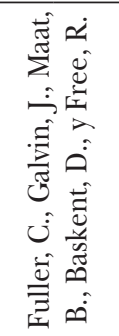 } & \multicolumn{3}{|c|}{$\begin{array}{l}\dot{n} \\
\dot{\Xi} \\
\dot{\Xi} \\
\dot{\Xi} \\
\dot{\Xi}\end{array}$} \\
\hline Z & \multicolumn{3}{|c|}{$\vec{\sigma}$} & ๙ิ & m & & & 10 & \multicolumn{2}{|c|}{ డి } & \multicolumn{3}{|c|}{ on } \\
\hline
\end{tabular}




\begin{tabular}{|c|c|c|c|c|c|c|c|c|c|c|c|c|c|c|}
\hline 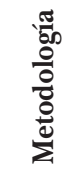 & \multicolumn{5}{|c|}{ 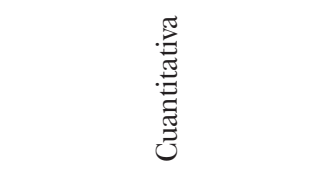 } & 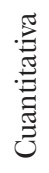 & & & \multicolumn{2}{|c|}{ 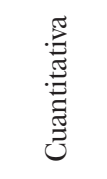 } & 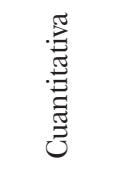 & \multicolumn{3}{|c|}{ 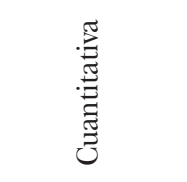 } \\
\hline 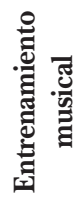 & \multicolumn{5}{|c|}{ 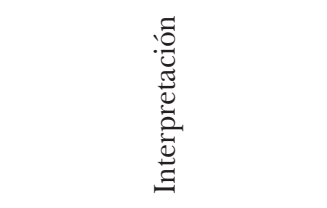 } & 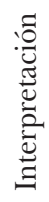 & & & \multicolumn{2}{|c|}{ 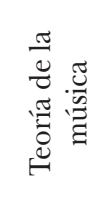 } & 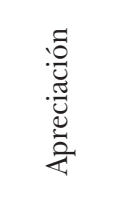 & \multicolumn{3}{|c|}{ 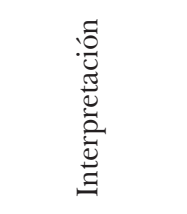 } \\
\hline 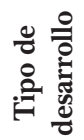 & \multicolumn{5}{|c|}{ 苞 } & 䓂 & & & \multicolumn{2}{|c|}{ 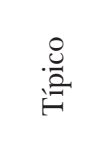 } & 惫 & \multicolumn{3}{|c|}{ 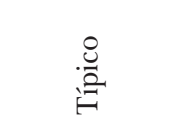 } \\
\hline 胥 & \multicolumn{5}{|c|}{ 1' } & $\stackrel{10}{4}$ & \multicolumn{2}{|c|}{\begin{tabular}{l}
$\dot{z}$ \\
\multirow{z}{*}{} \\
\multirow{2}{*}{} \\
$\infty$ \\
$\infty$
\end{tabular}} & \multicolumn{2}{|c|}{$\sigma$} & $\stackrel{\infty}{\infty}$ & \multicolumn{3}{|c|}{$\begin{array}{l}\infty \\
1 \\
1\end{array}$} \\
\hline Z & \multicolumn{5}{|c|}{ 先 } & $\underset{⿱}{*}$ & \multicolumn{2}{|c|}{$\underset{J}{J}$} & \multicolumn{2}{|c|}{ 会 } & $\ddot{6}$ & \multicolumn{3}{|c|}{ ది } \\
\hline 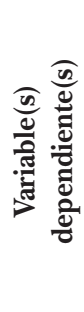 & 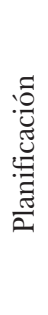 & 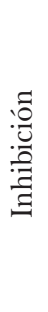 & 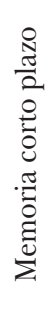 & 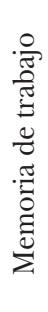 & 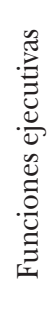 & 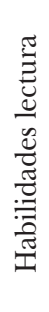 & 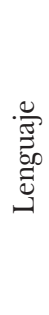 & . & 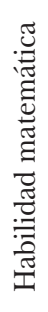 & 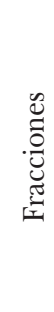 & 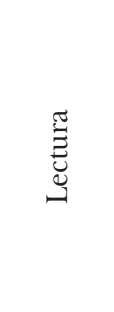 & 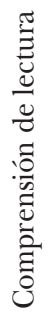 & 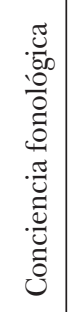 & 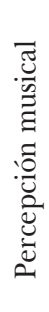 \\
\hline 宗 & \multicolumn{5}{|c|}{$\stackrel{\infty}{\stackrel{\infty}{\sim}}$} & $\stackrel{\infty}{\stackrel{\infty}{\sigma}}$ & & & \multicolumn{2}{|c|}{$\stackrel{\stackrel{\sigma}{\vec{D}}}{\vec{\sigma}}$} & 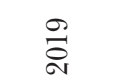 & \multicolumn{3}{|c|}{$\stackrel{\vec{a}}{\vec{\sigma}}$} \\
\hline 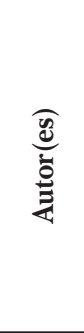 & \multicolumn{5}{|c|}{ 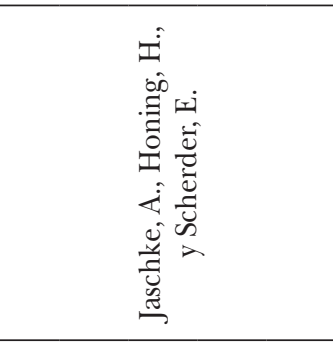 } & 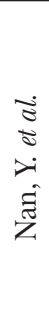 & \multicolumn{2}{|c|}{ 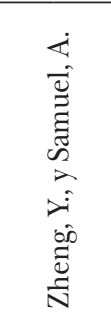 } & \multicolumn{2}{|c|}{ 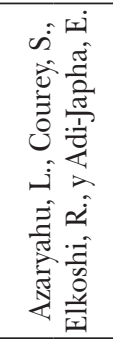 } & 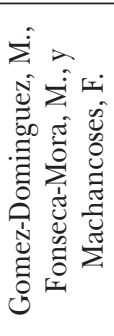 & \multicolumn{3}{|c|}{ 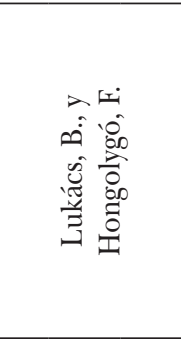 } \\
\hline 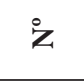 & \multicolumn{5}{|c|}{$\infty$} & ஜ) & & & \multicolumn{2}{|c|}{$F$} & भ̛ & \multicolumn{3}{|c|}{$\stackrel{\infty}{+}$} \\
\hline
\end{tabular}




\begin{tabular}{|c|c|c|c|c|c|c|c|c|c|c|c|c|c|}
\hline $\begin{array}{l}\text { 苟 } \\
\frac{0}{0} \\
\frac{0}{0} \\
\frac{0}{0} \\
\frac{0}{2}\end{array}$ & \multicolumn{6}{|c|}{ 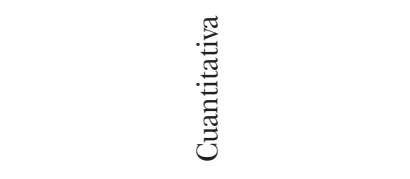 } & 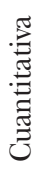 & \multicolumn{4}{|c|}{ 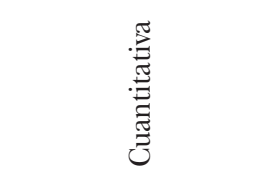 } & & \\
\hline 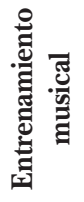 & \multicolumn{6}{|c|}{ 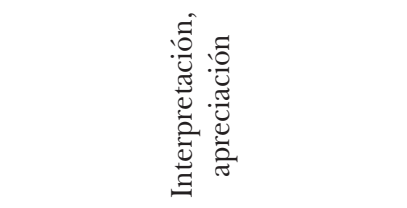 } & 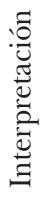 & \multicolumn{4}{|c|}{ 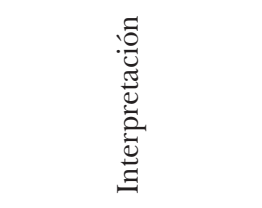 } & & \\
\hline 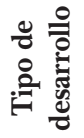 & \multicolumn{6}{|c|}{ 总 } & 总 & \multicolumn{4}{|c|}{ 总 } & \multicolumn{2}{|c|}{ 总 } \\
\hline 융 & \multicolumn{6}{|c|}{ ţ } & $\begin{array}{l}\stackrel{P}{1} \\
\text { I- }\end{array}$ & \multicolumn{4}{|c|}{ b } & \multirow{2}{*}{\multicolumn{2}{|c|}{$\frac{10}{6}$}} \\
\hline Z & \multicolumn{6}{|c|}{ 욱 } & \% & \multicolumn{4}{|c|}{ ๙ี } & & \\
\hline 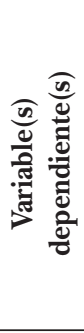 & 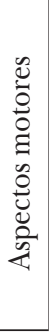 & 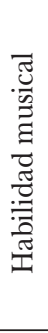 & & 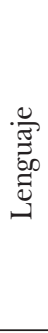 & 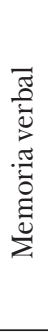 & 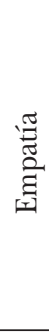 & 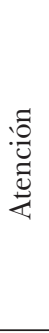 & 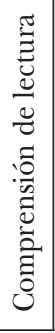 & 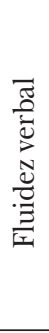 & 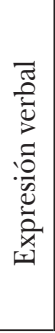 & 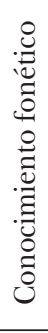 & 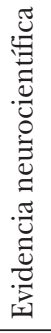 & 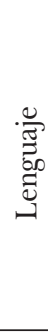 \\
\hline 宗 & \multicolumn{6}{|c|}{ 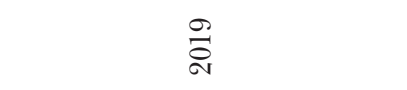 } & 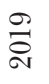 & \multicolumn{4}{|c|}{$\stackrel{\stackrel{\rho}{\vec{\sigma}}}{\text { ه }}$} & \multicolumn{2}{|c|}{$\stackrel{\circ}{\stackrel{a}{a}}$} \\
\hline 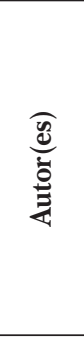 & \multicolumn{6}{|c|}{ 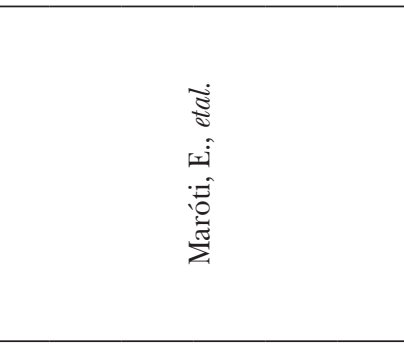 } & 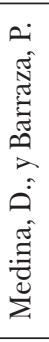 & \multicolumn{4}{|c|}{ 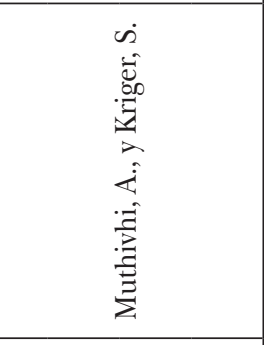 } & \multicolumn{2}{|c|}{ 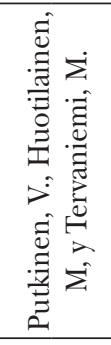 } \\
\hline Z & \multicolumn{6}{|c|}{ 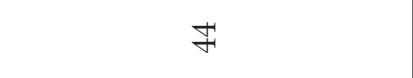 } & I8 & \multicolumn{4}{|c|}{$\mathscr{q}$} & \multicolumn{2}{|c|}{ F } \\
\hline
\end{tabular}




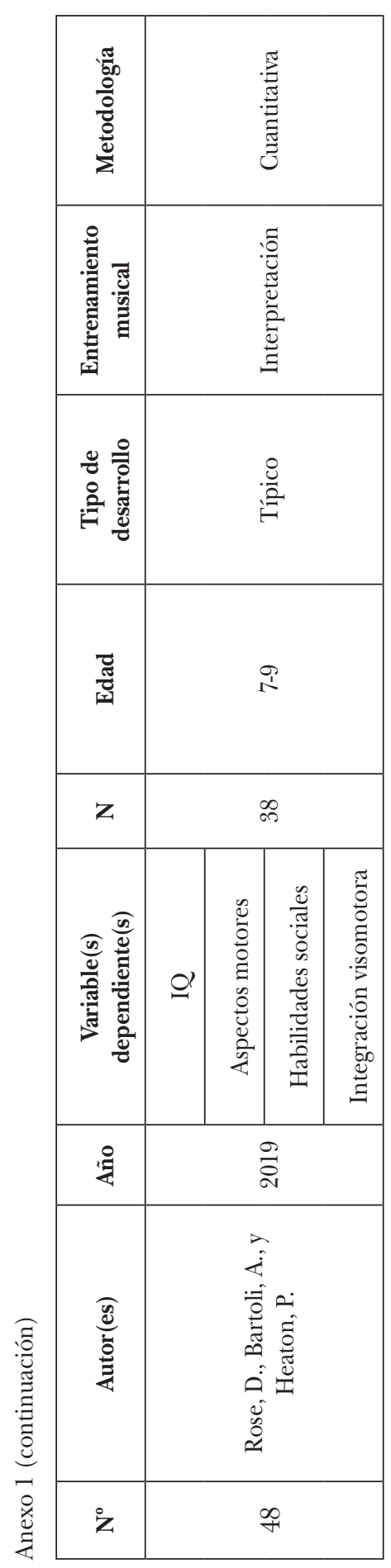

